\title{
Supernatural punishment, spiritual violence and the Gospel of Matthew
}

S piritual violence is a modern concept expressing the abusive aspects of religion. This article observes the potential for spiritual violence within the rhetoric of the Gospel of Matthew, a principal text of the dominant world religion. Utilizing the supernatural punishment hypothesis of religion as a theoretical background, this cross-disciplinary analysis opens perspectives on the use of religious power in the past and the present.

\section{Introduction}

The concept of spiritual violence is used to define the misuse of religious power, interconnecting sociological, psychological, juridical, theological and moral dimensions of religiously motivated conduct. One definition of this concept can be found in the dictionary of the Finnish Evangelical Lutheran Church, often cited in the Finnish literature concerning this subject (Hurtig 2013: 152; Linjakumpu 2012: 217-18; Linjakumpu 2015: 61; Ruoho 2013: 21; Villa 2013: 207). In this definition, 'spiritual violence is mental violence, which contains a religious dimension. It appears as intimidation, conversion, accusation, isolation and control. The purpose is to discourage the view of life, lifestyle and opinion of another person' (Jussila et al. 2004: 95, my translation).

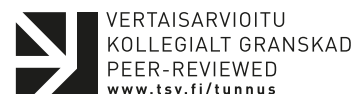

PEER-REVIEWED
www.tsv.fi/tunnus

From the teaching of Jesus depicted in the Gospel of Matthew, his actions seem to match all the parts of this definition: he often intimidates his listeners with the imminent divine judgement (Matt. 25:146) and is willing to convert everyone to follow his teaching $(28: 20)$. He accuses people of bad words (12:24-37), deeds (23:37-9) and even thoughts (5:28), and makes strict divisions between his own and the others (15:21-6). He teaches his followers to control their conduct $(5: 20-30)$ and the conduct of others (18:15-18). He uses harsh words to discourage the views of life, lifestyles and opinions of others (23:13-33).

Jesus may be called an enactor of spiritual violence, but this raises several questions, not only concerning the supposedly Christ-centred identity of the church presenting the definition of the concept, ${ }^{1}$ but also concerning the somewhat paradoxical nature of the definition itself: the concept of spiritual violence can be used to discourage the view of life, lifestyle and opinion of another person, so as to label someone

1 In the New Testament and subsequent Christian doctrine, Jesus is presented as a moral exemplar who is totally free of sin (2 Cor. 5:21; Heb. 4:15). 


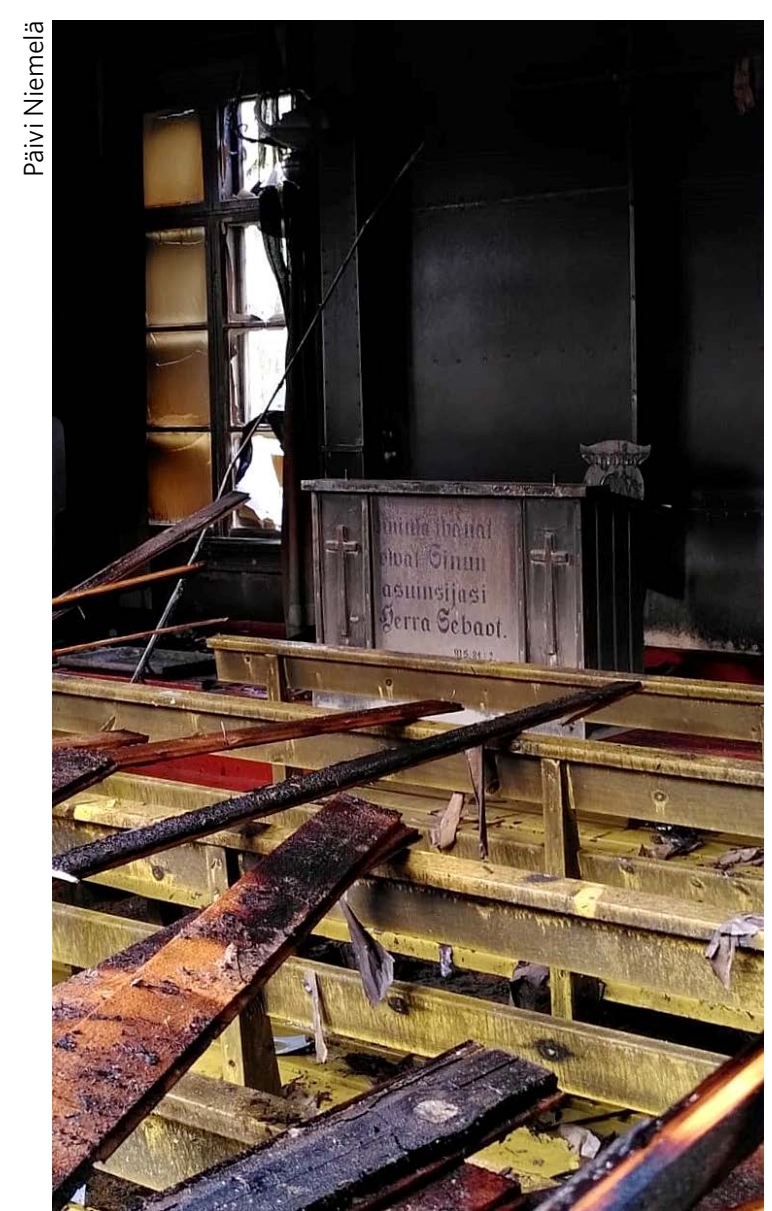

Pulpit of the prayer house of Yppäri, which was destroyed by arson in 2020. The prayer house was built in 1949 in collaboration between three branches of the Laestadian Lutheran revival movement. Interiors were designed, crafted and painted by Einari Laaksonen.

as a representative of unhealthy religion. ${ }^{2}$ Despite problems of this kind in defining the concept of spiritual violence, the phenomena listed in the definition above should not be ignored as challenges to the

2 The dictionary also makes a distinction between healthy and unhealthy religion. The risk of spiritual violence is recognized within all religious groups. The risk is increased in fundamentalist sects with strong charismatic leadership (Jussila et al. 2004: 95). present-day spiritual life. Being among the most well-known and cited texts of the biggest world religion, the Gospel of Matthew has not lost its influence on the social dynamics of religious groups. Hence, we shall examine the rhetoric of the First Gospel more closely.

Does the Gospel of Matthew indeed contain such violent ways of communication, and does the popularity of the book and the concomitant religion have any connection with the harsh tones of the text? In this article, I will approach these questions from theoretical perspectives provided by the cognitive and evolutionary study of religion, especially by the supernatural punishment hypothesis of religion. The first part of the article gives a theoretical basis for the following parts, summing up the history of the concept of spiritual violence, and the supernatural punishment hypothesis of religion. The second part of the article consists of an exegetical analysis of the traits of spiritual violence in the Gospel of Matthew. The results and implications of the analysis are summed up in the conclusion.

\section{Spiritual violence and the supernatural punishment hypothesis}

In the following section, I describe the concept of spiritual violence, and the basics of the supernatural punishment hypothesis of religion. For the former, I mostly utilize the work of Aini Linjakumpu on the concept of spiritual violence. For the latter, I focus on the views of Dominic D. P. Johnson, a central developer of the supernatural punishment hypothesis. I then consider how these concepts relate to each other.

\section{Spiritual violence}

The concept of spiritual violence has mainly been formed as a product of societal discussions involving churches, social 
workers, targets of violence and scholars (Linjakumpu 2015: 60). Being based on different field experiences rather than academic discussion, the concept has no single agreed definition (Linjakumpu 2016: 183). In the international and especially Northern American context, the abuse of religious power has traditionally been approached along with other concepts, such as brain-washing, mind control, psychological enslavement, undue influence, coercive persuasion and spiritual abuse (Linjakumpu 2015: 61). Aini Linjakumpu, however, considers these concepts insufficient in understanding the entirety of spiritual violence. She argues that connecting these definitions under the concept of violence facilitates all-round examination of the phenomenon, intertwining them into the constructs of control and power in communities (pp. 65-6). She defines spiritual violence as an in-group phenomenon, and separates it from the wider concept of religious violence, in which out-groups are also targeted (p. 58). She has defined the concept as follows:

Spiritual violence is mental or physical violence, targeted against the members of a religious community of one's own. It is reasoned on spiritual grounds or membership in a religious community. It is experiential violence that violates the rights of a human being, and their potential for defining their agency, spirituality and future. Spiritual violence does not end with the imminent violent situation, but may have long-lasting consequences, possibly also involving other people. It is difficult to resist spiritual violence, owing to its nature: it is connected with the mechanisms of power and control in religious community, the legitimacy of which is supposed to be of divine origin. (Linjakumpu 2015:

66, my translation)

In Linjakumpu's (2016) wider description of spiritual violence, four dimensions are worth noting here: spiritual violence is contextual and processual, and often also structural, and even conventional. Structural violence is violence inherent in and enabled by social structures, being unintentional or impersonal in its very nature. Hence, for some, structural violence appears as a normal procedure, whereas others experience the violence (Galtung 1969: 170-1; Linjakumpu 2016: 185). Even though the basic nature of structural violence is not intentional or personal, violence is always a process involving persons. Hence, the subjects involved in structural violence may be more or less conscious of the violent dimension of their action (Linjakumpu 2016: 186). Moreover, structural violence does not show violence as an automatic consequence of known social structures, nor prove the inevitably violent nature of some religious movement. Rather the perspective of structural violence shows potential behind processes, situations and subjects (p. 186). High-intensity violence

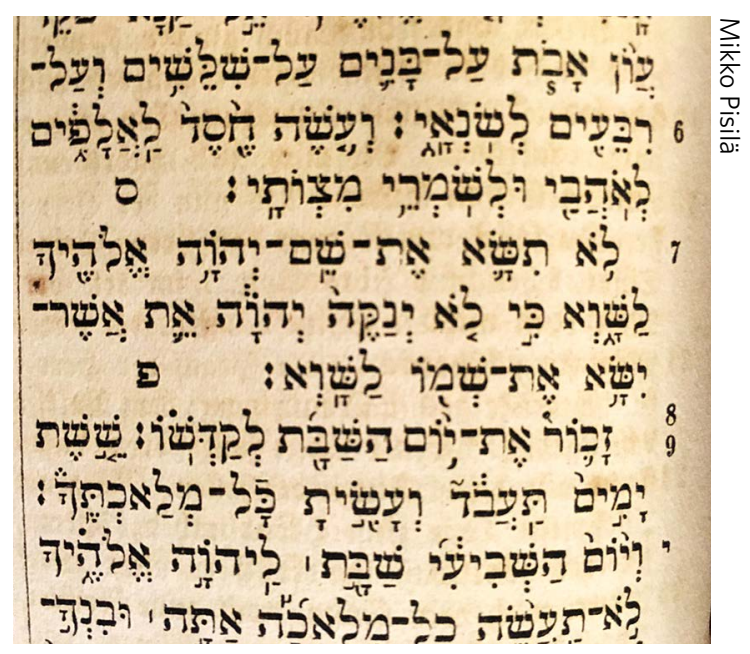

Exodus 20:7 in the Polyglotten-Bibel, printed in 1854 (Bielefeld: Velhagen \& Klasing). 
is exceptional within religious communities, but one should not neglect the traits of spiritual violence potentially occurring in their conventional activity (p. 182; Eller 2007: 219).

Concerning the structural nature of spiritual violence, I would also like to quote a definition of spiritual violence by Theresa W. Tobin: 'Spiritual violence is distinctively spiritual both in terms of its means and its target. It occurs when churches or their agents use religiously significant symbols, texts, teachings, rituals, prayers, or religious leaders to violate or threaten a person's spiritual self, including their experience of or capacity for relationship with God' (Tobin 2019: 5). In this article, the Gospel of Matthew is seen as a foundational and conventional part of social structures of religious groups, and as a religiously significant text that may be used for spiritual violence. For Johan Galtung, the Gospel of Matthew is seen as a source of cultural violence. In his triad of violence, 'Direct violence is an event; structural violence is a process with ups and downs; cultural violence is an invariant, a "permanent", remaining essentially the same for long periods, given the slow transformations of basic culture' (Galtung 1996: 199, footnote omitted).

According to Linjakumpu (2015: 13), 'spiritual violence is always contextual violence.' In other words, violence is not always similar for everyone, but the exposure to violence depends on several factors in the subjects, more and less vulnerable victims, and the socio-historical context of violence (Linjakumpu 2016: 186, 188). The sociohistorical context also matters in recognizing or defining violence:

Defining violence as violence is a political process, in which something seen as nonviolent will be interpreted as violent. This is a process of vio- lence becoming politicized, in which things, situations, and events will be understood otherwise: non-violence becomes violence in processes of politicization. The process of politicization seldom goes without contradiction. The speech on spiritual violence has also produced many different and even opposing views on the meaning of spiritual violence in public discussions. For others a certain thing may be an act of love, whereas other human being sees it as violence. The meaning of 'spiritual violence' is also unclear on broader societal level. (Linjakumpu 2016: 182-3, my translation)

The concept of violence is thus culturally relative and 'slippery', and there is no categorical or context-free definition of it (Linjakumpu 2016: 183; Eller 2007: 220). On the other hand, relativization of violence and letting each group have its own definition is also problematic. Definitions of violence have their normative consequences (Linjakumpu 2016: 183). In this article, I have chosen to utilize the definition of Finnish Evangelical Lutheran church in my analysis, because of its practical categorizations of spiritual violence appearing as intimidation, conversion, accusation, isolation and control. Applying these categorizations to the rhetoric of Matthew, one should be mindful of the socio-cultural gap between the origins of the text and today's world, and the potential of violence inherent in the normative power of definitions like this. However, the combination of violence as a challenge to the essence of humanity, and the persistent significance of Matthew in present-day spirituality, calls for an analysis.

The violent dimensions of the rhetoric of Matthew should be seen from the perspective of the surrounding cultural 
context, where philosophical and religious contradictions were often dealt with in vituperative language (Johnson 1989; Olivares 2016). Moreover, the rhetoric of hell strongly present in the Gospel of Matthew has firm roots in Jewish religious texts and Hellenistic pedagogical tradition (Henning 2014). One should be careful too not to exaggerate or downplay the severity of harsh rhetoric, as Peter Lampe (2010: 339) brilliantly notes: 'in all hermeneutical attempts we should not forget that verbal violence, streaming from a pen, is not the same as bloodshed flowing down a sword. However, it can lead there, and in church history it did.'

\section{Supernatural punishment}

Considering the cultural relativity of the concept of spiritual violence, and the socio-cultural gap between the origin of the Gospel of Matthew and its present-day reception, our analysis needs to be backed up with a cross-culturally tested cognitive and evolutionary approach. The supernatural punishment hypothesis (also known as the supernatural punishment theory) seeks to answer the problem of cooperation, which is the basic problem of group life from the perspectives of game theory and evolution: a cooperative group will collapse if its members consume the resources of the group instead of gathering them. The larger the group becomes, and its members more distant genetically and socially, the more challenging this problem becomes (Johnson and Krüger 2004: 160). To avoid the effect of counterproductive individuals, often referred as 'free-riders', surveillance and punishments are an essential element of human group life (p. 160). According to the supernatural punishment hypothesis, the effect of surveillance and punishments in promoting cooperation can be enhanced significantly when the limited capacities of norm-enforcement by human agents are (allegedly, at least) complemented with surveillance and punishments by supernatural agents (pp. 163, 173-4). ${ }^{3}$ This hypothesis, originally presented in 2004, has been reinforced in numerous field studies, simulations and social experiments (Johnson 2005, 2018; Johnson and Krüger 2004; Purzycki et al. 2016). Moreover, the ideas of supernatural surveillance and punishments are recognizable in the major world religions (Johnson 2016: 43-9). The fundamental aspects of the supernatural punishment hypothesis can be summed up as follows:

Among the other factors that influence the emergence of human ultrasociality and complex societies, the diffusion of explicit beliefs in increasingly moralistic, punitive and knowledgeable gods may have played a crucial role. People may trust in, cooperate with and interact fairly within wider social circles, partly because they believe that knowing gods will punish them if they do not. Additionally, through increased frequency and consistency in belief and behaviour sets, commitments to the same gods coordinate people's expectations about social interactions. Moreover, the social radius within which people are willing to engage in behaviours that benefit others at a cost to themselves may enlarge as gods' powers to monitor and punish increase. (Purzycki et al. 2016: 327 , footnotes omitted)

3 Johnson (2018: 327) enlists no less than ten mechanisms by which the threat of supernatural agents are effective, even for those sceptical of their existence. 


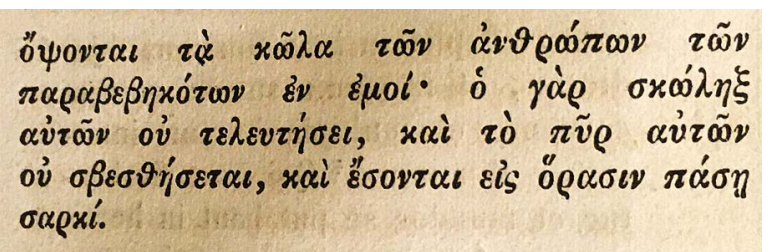

Isaiah 66:24 in the Polyglotten-Bibel.

The evolutionary processes covered by the supernatural punishment hypothesis are both genetic and cultural. Dominic D. P. Johnson (2018: 339) explains this distinction as follows: ' $(1)$ the underlying cognitive dispositions that enable religious beliefs and behavior - e.g., sensitivity to threats, theory of mind, cause and effect reasoning - are genetic adaptations, while (2) the specific beliefs that supernatural agency $\mathrm{X}$ carries out supernatural punishment $Y$ for doing activity $\mathrm{Z}$ are cultural phenomena.' Obviously, the scope of this article covers the cultural side, as the Gospel of Matthew is examined as a cultural product reinforcing the evolutionary mechanisms of surveillance and punishment.

\section{Evolution, punishment and violence}

The supernatural punishment hypothesis provides evolutionary reasoning for the phenomena addressed with the concept of spiritual violence. As moralistic, punitive and knowledgeable gods become agents of surveillance and punishments, we gain another definition of spiritual violence to complement the earlier ones. Considering the categorization of spiritual violence that I have chosen to make use of in my analysis of Matthew, we can see intimidation, conversion, accusation, isolation and control as categories associated with surveillance and punishments: religious rhetoric of intimidation, conversion and accusation rely on the whole on the threat of supernatural punishments. Moreover, isolation is a social punishment which complements the effects of supernatural punishments. The category of control, obviously, relies on social and supernatural surveillance. Hence, this categorization is helpful for understanding the cultural promotion of supernatural surveillance and punishments.

On the other hand, the evolutionary perspective is also helpful for understanding the cultural relativity and political nature of the concept of spiritual violence. As Johnson suggests, 'it may be that religion helped to solve precisely the cooperation problems that arose in domains of insecurity - food, weather, reproduction, illness, death, war, and so on. On issues that made people rightly anxious, religion, and in particular supernatural punishment, offered a tool close to hand to leverage cooperation from the jaws of self-interest (Johnson 2018: 335). My suggestion is that the emergence of the concept of spiritual violence indicates a cultural development in which supernatural punishments have become less necessary at the level of society; the concept of spiritual violence, be it noted, has been developed in societies with relatively high security, such as (post) modern Canada and Finland (Linjakumpu 2015: 60-5). The concept of spiritual violence has its use in the social surveillance and punishments of the representatives of the religion that is seen to do more harm than good in certain socio-cultural contexts. This aspect of power and control is what I call the paradox of spiritual violence. This concept reminds us of the tension of contradictory perspectives that is inherent in the concept of violence. As Jesus teaches in the Gospel of Matthew, 'with the judgment you make you will be judged, and the measure you give will be the measure you get' (Matt. 7:2 NRSV). Using the categorization of spiritual violence presented by the Finnish Evangelical Lutheran Church 
in my analysis of Matthew, I am also pointing out how the church has entered into a political process of defining the Matthean Jesus - perhaps unintentionally - as a perpetrator of spiritual violence.

\section{Spiritual violence in the text of Matthew}

For the second part of this article, I analyse the occurrence of traits of spiritual violence in the rhetoric of the Gospel of Matthew. These traits are categorized as intimidation, conversion, accusation, isolation and control; the applicability of this rhetoric in present-day spiritual violence is also considered. The analysis is focused on chapter 18 of Matthew, addressing different traits of spiritual violence that occur in it. For each trait of spiritual violence, the analysis aims to give an overall picture of the phenomenon in the Matthean rhetoric, with selected examples taken from across the Gospel of Matthew.

Before the text analysis, I would like to relate my research question to the history of research into Matthew, and to mention an article by Warren Carter, 'Construction of violence and identities in Matthew's gospel' (2005), as perhaps the closest parallel consideration of my research question. Carter paints an overall picture of the acts and traits of violence performed by different social strata, institutions, geographical and other collectives, and supernatural agents in Matthew's narrative. In his conclusions, he sums up the somewhat paradoxical role of violence in the Gospel narrative as follows:

Matthew's Gospel thus constructs violence theologically. It regards it as central to the sinful human societal situation from which Jesus is to save people (1:21); as deeply enmeshed in and expressed by the current elitedominated, imperial, societal struc- ture; as inevitable to the conflict over the competing societal visions that come into sharp collision through Jesus' life and death; and as crucial to the divine completion of that salvation in Jesus' return and resultant judgment. In resisting and redeeming the violence of the imperial status quo, the gospel also affirms that some violence, namely the violence of God, the supreme ruler who is 'Lord of heaven and earth' (11:25), and of God's agent Jesus, is legitimate and necessary.

Given Jesus' rhetorically violent condemnation of the status quo, his physically violent anticipation of judgment in his temple actions, and the violent visions of God's eschatological triumph accomplished through Jesus' parousia and eschatological battle, Matthew's gospel finally, but ironically, capitulates to and imitates the imperial violence from which it seeks to save. (Carter 2005: 102)

Even though not mentioning the concept of spiritual violence, the conclusions above provide a good socio-cultural and rhetorical background for my analysis, within which the present topic of research is more specific. Whereas Carter depicts the violence performed by all actors in Matthew's narrative, my attention is on the texts that have most relevance in relation to present-day spiritual violence. In Carter's terms, this stands for his category of violence performed by Jesus or God (Carter 2005: 89-90, 97-102). In Matthew's narrative, the disciples of Jesus form a community of non-violence, the only small crack in this picture being the swordsman whose violent action is rebuked in Matt. 26:51-2 (p. 97). 
Recognizing the socio-historical background of the text, I approach the narrative of Matthew as a cultural product, not problematizing the historicity and sequence of the characters and events presented. ${ }^{4}$ Thus, 'Matthew' and 'Jesus' are not used as names of historical persons, but as the names of a literary composition and the main character in it, respectively. Biblical quotations are from the New Revised Standard Version (NRSV).

\section{Spiritual violence in Matthew 18 Matthew 18:1-5}

1 'At that time the disciples came to Jesus and asked, "Who is the greatest in the kingdom of heaven?" $2 \mathrm{He}$ called a child, whom he put among them, 3 and said, "Truly I tell you, unless you change and become like children, you will never enter the kingdom of heaven. 4 Whoever becomes humble like this child is the greatest in the kingdom of heaven. 5 Whoever welcomes one such child in my name welcomes me."'

At the very beginning of Matthew 18, Jesus denies his disciples entry to the kingdom of heaven - an implicit threat of supernatural punishment - unless they profoundly change. This is what we may call the rhetoric of conversion, even though the concept of conversion is somewhat unclear in biblical context (Gaventa 1992:

4 Most scholars believe that the Gospel of Matthew was composed in Syria, most probably in Antioch, in the final quarter of the first century AD. For further information on the authorship, structure, literary characteristics, sources, date and local origin of Matthew, see Davies and Allison 2004: 1-147.
42). According to Beverly Roberts Gaventa, there are at least three forms of conversion in the New Testament, namely alternation, pendulum-like conversion and transformation. She explains these forms of conversion as follows:

An alternation is a conversion that develops naturally out of previously established life patterns. For example, when a Methodist marries a Presbyterian and joins the Presbyterian church, that individual is a convert, but one whose conversion has followed rather than disrupted already established convictions. Pendulum-like conversion is conversion in which the individual's past is rejected in favor of a newly chosen religious system. Here we might take as an example a young person growing up in a nominally Christian home in a North American context, who later leaves that setting for the Unification Church. That individual rejects his or her past for what is understood to be a radically different future. Transformation occurs when the past faith of an individual is not rejected, but reinterpreted in the new experience. A possible illustration of this kind of conversion is the experience of Martin Luther, whose reading of scripture caused him to radically reinterpret his past. These are not, of course, mutually exclusive categories. Nor are they exhaustive of the kinds of conversion that occur. They may, nevertheless, be helpful as we examine the biblical texts, particularly as a reminder that not all conversion experiences are the same. (Gaventa 1992: 42-3) 

2 Sröbelte im Scimmelreich? * Sejus rief ein Rino 3 zu fich und ftellete bas mitten unter fte, *uno

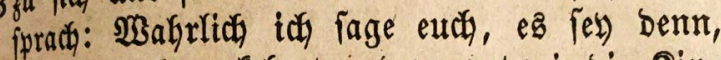
bap ify euch umfelgret und werdet wie die Sin= Ser, fo merbet ify nicht ins Scimmelreich fom= 4 men. * Nor nun fta felfft exniebriget, wie

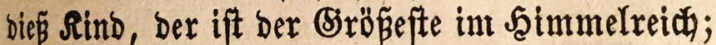
5 *uns wer ein folcaes Sins aufnimmt in mei=

Matthew 18:1-5 in the Polyglotten-Bibel.

Our citation from the Gospel refers to a conversion that contains elements of both rejecting and reinterpreting one's past: the disciples are called not to reject their past commitment to the teachings of Jesus, but to reinterpret it in a profound way. In this process, they should reject their pursuit of power and social status and imitate a child in order to renew their identity. In the Gospel of Matthew, following Jesus means radical transformation of one's identity, to the point of rejecting everything in one's past. In addition to the encounter of Jesus and the wealthy young man in Matt. 19:1630 , this is especially explicit in 16:21-8, where Jesus reveals his imminent suffering to his disciples. As Peter is terrified of this idea of messianic suffering (16:22), Jesus persuades Peter to reject his mindset by identifying him as Satan (16:23) and insists everyone willing to follow him 'take up their cross' (16:24) and 'lose their life' for his sake (16:25). These exhortations are intensified with rhetorical refences to supernatural surveillance and punishments, as it is promised that the Son of Man will come soon and 'repay everyone for what has been done' (16:27-8).

From a broader perspective, the rhetoric of conversion creates a significant theme in the Gospel of Matthew. As a basic motive of Matthean ideology, the proclamation of the

kingdom of heaven (Matt. 4:17; 10:7) calls its audience to reject insufficient righteousness $(5: 20)$ and a sinful, destructive way of life $(7: 13-14)$. The tribes of Israel (10:6) and finally all nations (28:19) should become disciples of Jesus. Conversion in the teachings of Jesus and in the rhetoric of the Gospel of Matthew is thus significant, as this call for all to follow Jesus forms a rhetorical climax in the whole literary composition (Hagner 1995: 881).

In the context of Matthew, entering the kingdom of heaven stands for self-denial and an unquestioning personal and ethical commitment to Jesus and his teaching, and not letting Satan convert one away from the narrow path of heaven. From the perspective of spiritual violence, the Gospel of Matthew gives a mandate to convert anyone whose personal or ethical commitment to Jesus is questionable. As Ulrich Luz states, regarding the mission commandment, 'against the ambivalent history of our text's interpretation stands its clear and unequivocal claim: mission, understood as proclamation of Jesus' teaching and call to discipleship, is according to $28: 18-20$ an indispensable characteristic of the church' (Luz 2005: 636).

\section{Matthew 18:6-9}

6 'If any of you put a stumbling block before one of these little ones who believe in me, it would be better for you if a great millstone were fastened around your neck and you were drowned in the depth of the sea. 7 Woe to the world because of stumbling blocks! Occasions for stumbling are bound to come, but woe to the one by whom the stumbling block comes! ${ }^{8}$ If your hand or your foot causes you to stumble, cut it off and throw it away; it is better for you to enter life maimed 
or lame than to have two hands or two feet and to be thrown into the eternal fire. 9 And if your eye causes you to stumble, tear it out and throw it away; it is better for you to enter life with one eye than to have two eyes and to be thrown into the hell of fire.'

These verses contain rhetoric of intimidation and control. The figure of the $\sigma \kappa a ́ v \delta a \lambda o v$, 'stumbling block' or 'snare', derives from the Greek Septuagint translations of the corresponding expressions יִכְש (mikshol) and (yaqosh) in the Hebrew Bible. Although the figurative speech of the cited passage is 'exceedingly difficult' (Luz), it can be understood as a general reference to events leading to apostasy (Davies and Allison 2004b: 762; Hagner 1995: 522, Luz 2001: 432-3). The intimidating supernatural punishment of evil-doers is depicted as 'eternal fire' and 'hell of fire', which is worse than cutting off one's hand or foot, tearing off one's eye, or being drowned in the depth of the sea with a millstone. The rhetoric of cutting limbs and tearing eyes is the rhetoric of control that also occurs in Matt. 5:27-30 in a context of avoiding adultery. This figurative language calls for radical separation from evil (Luz 2001: 436). This rhetoric of control seeks to be internalized as self-control, thus restricting the choices to be made in the life of a follower of Jesus in a way that can be seen as spiritual violence:

Violence is something that restricts a human being from having the opportunity for certain actions and certain ways of existence. Regarding spiritual violence, this means paying attention to things that perhaps do not appear as the most obvious dimensions of violence. In this interpretation, the consequences of violence should be assessed in relation to the potential of constructing the ego, identity, practices of life and the action of a human being in the absence of the violence. Violence, therefore, is about

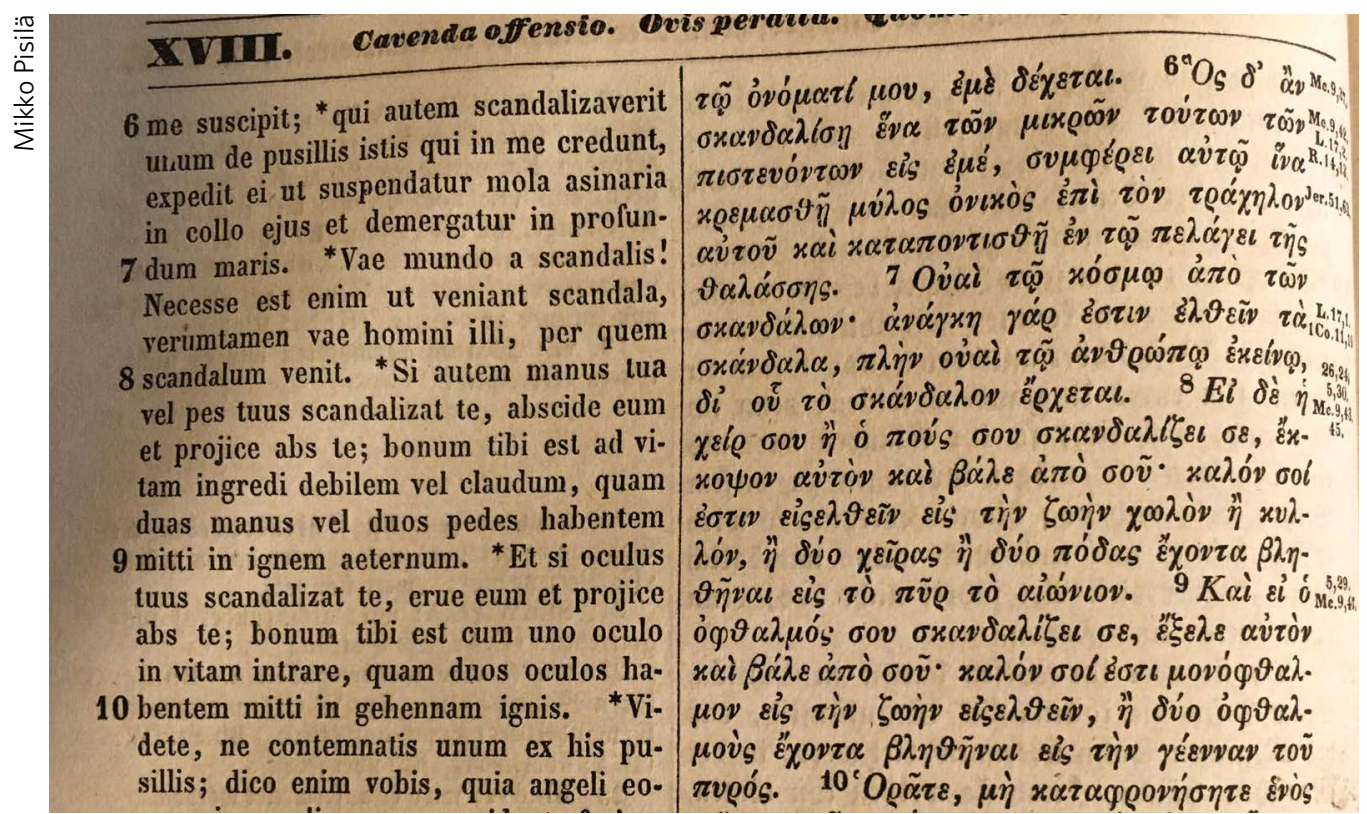

Matthew 18:6-9 in the Polyglotten-Bibel. 
the potential for a human being to act in the world, and the conditions of the action (see also Staudigl 2007: 245-8). (Linjakumpu 2016: 187, my translation)

In her interpretation, Linjakumpu refers to Michael Staudigl, who seems to explain the Matthean rhetoric of bodily mutilations: 'Even if it does not touch the objective body, language, especially in its violent forms, indeed "transfigures the body" (Merleau-Ponty 2006: 229). By modifying or revaluating our "I can", language elementarily affects the bodily ways we inhabit the inter-subjective world, and, thus, transforms the way we appear to ourselves' (Staudigl 2007: 249).

Being conscious of the power of language, the Gospel of Matthew also promotes control over one's verbal conduct. In chapter 12, there is a warning from Jesus $(12: 36-7)$ : 'I tell you, on the day of judgment you will have to give an account for every careless word you utter; for by your words you will be justified, and by your words you will be condemned.' This warning is given in a context of blasphemy (12:24-34), in which the threat of supernatural punishment is, given its inevitability, the most intimidating in the rhetoric of the Gospel (12:31-2): 'Therefore I tell you, people will be forgiven for every sin and blasphemy, but blasphemy against the Spirit will not be forgiven. Whoever speaks a word against the Son of Man will be forgiven, but whoever speaks against the Holy Spirit will not be forgiven, either in this age or in the age to come.' According to Ulrich Luz, this saying is not only intimidating, but it is also useful for social punishment of isolation:

We are aware from many biographies how in the course of church history sensible and pious people were tortured by the fear that they had committed the unforgivable sin against the Holy Spirit. Today the sin against Holy Spirit has largely disappeared from dogmatics. However, it still shows up in the case histories of religious people in psychiatric clinics. ... The other problem lies in the function of this saying. It was able to be used quite well for condemning heretics and thus for justifying oneself, not least of all in its Augustinian application to the church. The list of those whom the church authorities with its help have consigned into eternal darkness is impressive and reaches from Simon Magus over the Arians to the 'Papists and rabble who willfully oppose our teaching. (Luz 2001: 206-8, footnotes omitted)

\section{Matthew 18:11-20}

11 'Take care that you do not despise one of these little ones; for, I tell you, in heaven their angels continually see the face of my Father in heaven. 12 What do you think? If a shepherd has a hundred sheep, and one of them has gone astray, does he not leave the ninety-nine on the mountains and go in search of the one that went astray? 13 And if he finds it, truly I tell you, he rejoices over it more than over the ninety-nine that never went astray. 14 So it is not the will of your Father in heaven that one of these little ones should be lost. 15 "If another member of the church sins against you, go and point out the fault when the two of you are alone. If the member listens to you, you have regained that one. ${ }^{16}$ But if you are not listened to, take one or two others along with you, so 
15 Si autem peccaverit in te frater tuus, vade et corripe eum inter te et ipsum solum; si te audierit, lucratus eris fra16 trem tuum. *Si autem te non audierit, adhibe tecum adhuc unum vel duos, ut in ore duorum vel trium testium stet 17 omne verbum. * ${ }^{*}$ uod si non audierit eos, dic ecclesiae; si autem ecclesiam non audierit, sit tibi sicut ethnicus et 18 publicanus. *Amen dico vobis, quaecumque alligaveritis super terram, erunt

Matthew 18:15-17 in the Polyglotten-Bibel.

that every word may be confirmed by the evidence of two or three witnesses. 17 If the member refuses to listen to them, tell it to the church; and if the offender refuses to listen even to the church, let such a one be to you as a Gentile and a tax collector. ${ }^{18}$ Truly I tell you, whatever you bind on earth will be bound in heaven, and whatever you loose on earth will be loosed in heaven. ${ }^{19}$ Again, truly I tell you, if two of you agree on earth about anything you ask, it will be done for you by my Father in heaven. ${ }^{20}$ For where two or three are gathered in my name, I am there among them."'

Instead of leading each other into temptation and sin, the followers of Jesus should take care of each other, imitating the laborious shepherding of the heavenly father. In terms of spiritual violence, this citation is all about control, accusation, conversion and isolation. From the perspective of the supernatural punishment hypothesis, it perfectly illustrates how supernatural surveillance and punishments, when proving insufficient, should be complemented by social surveillance and punishments.

In the narrative, the followers of Jesus are under supernatural surveillance by the heavenly father, pictured in parable as a shepherd, and by the angels of 'little ones', an ambiguous term which seems to refer to the disciples of Jesus, regardless of their age (Davies and Allison 2004b: 762-3; Hagner 1995: 521-2; Luz 2001: 432). The control of the heavenly father over his creation is all-inclusive, which is a reason to fear him instead of human beings (Matt. 10:2631). He will reveal every secret (10:26) and counts even the hairs of the heads of his children (10:30). This message of the unlimited power of God may either give comfort or cause anxiety in its audience (Luz 2001: 102, 105-6).

Imitating the heavenly shepherd, Jesus instructs his followers to control each other's conduct. If anyone sins, they are accused and called to convert: at first in private, then in front of witnesses, and, if necessary, in a public congregation (Matt. 18:15-17). If the individual does not admit their crime and submit under the control and heavenly authority $(18: 18,20)$ of the congregation, a social punishment of isolation should follow (18:17): 'Let such a one be to you as a Gentile and a tax collector.' W. D. Davies and D. C. Allison explain the saying as follows:

To treat someone as a Gentile and toll-collector would involve the breaking off of fellowship and hence mean exclusion from the community no doubt in hope that such a severe measure (it would have dire social and probably economic consequences) would convict the sinner of his sin and win him back (cf. 2 Thess 3.14; Titus 1.13; Calvin, Inst. 4.12.5). (Davies and Allison 2004b: 785)

In the whole Gospel of Matthew, there are no other references to exclusion of a member from the group of the followers of 
Jesus. The 'get behind me, Satan' directed towards Peter in Matt. 16:23 seems to have no harmful social consequences in the narrative, even though the rhetoric is harsh. In Matt. 15:21-8, Jesus uses rudely exclusive language towards a non-member, a Canaanite woman, in some degree resembling John the Baptist, who turns away a group of Pharisees and Sadducees from receiving his baptism with hostile language in Matt. 3:7-10. Even though a direct narrative example of excluding a member from the group following Jesus remains absent, it is notable that the Gospel of Matthew gives a fair number of examples of manifest social boundaries.

Social boundaries are regularly manifested in the rhetoric of the Gospel of Matthew, as different ethnic and religious groups are often presented as carefully separated, often even hostile entities. However, this does not happen without ambivalence. Regarding ethnicity, Jesus was initially rude towards the Canaanite woman, but he eventually praised her faith, as well as the faith of a non-Jewish centurion (Matt. 8:10, 15:28). He also initially turned away his apostles from Gentile mission, but eventually sent them to all nations (10:5, 28:19). More attention is given to the differences between religious groups and agents, and the picture is more stable here. ${ }^{5}$ Even though there are conversations and even some respect between the groups, the boundaries always remain, and open hostility is sometimes expressed (23:13-36). Both John the Baptist and Jesus express

5 For a deeper view of this topic, see Runesson 2016: 233-56. Runesson sees the authorship of the Gospel of Matthew as lying within a group of former Pharisees who were in the process of breaking away from the larger Pharisaic network (Runesson 2008; Runesson 2016: 251). open hostility towards their adversaries, and both of them eventually die as a result of the controversy raised by their teachings. From the perspective of spiritual violence, the Gospel of Matthew is full of language of social exclusion, which may find its use as spiritual violence.

In terms of control, the Gospel of Matthew promotes a controlled, highly disciplined way of life. The basis of this control is the constant and detailed supervision of the heavenly father. Living as his child, one should control oneself at any cost, which is demonstrated in a variety of teachings. As a backup for this self-control, the Gospel of Matthew explicitly promotes a mechanism of social control among the disciples of Jesus. If one refuses to conform with the views of the community, one is no longer seen as a member. From the perspective of spiritual violence, the teachings of the Matthean Jesus can be effectively used to control the life and identity of an individual.

\section{Matthew 18:21-35}

21 'Then Peter came and said to him, "Lord, if another member of the church sins against me, how often should I forgive? As many as seven times?" 22 Jesus said to him, "Not seven times, but, I tell you, seventyseven times. ${ }^{23}$ For this reason the kingdom of heaven may be compared to a king who wished to settle accounts with his slaves. ${ }^{24}$ When he began the reckoning, one who owed him ten thousand talents was brought to him; 25 and, as he could not pay, his lord ordered him to be sold, together with his wife and children and all his possessions, and payment to be made. ${ }^{26}$ So the slave fell on his knees before him, saying, 'Have patience with me, 


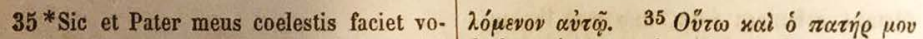

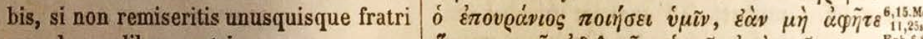
suo de cordibus vestris.

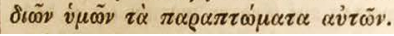

35 war. *21jo wiro euđ mein bimmlijđjer $\mathfrak{B a t e r}$ auth thum, fo ifr nidgt wergebet bon eurem ફ̧erzen, ein jeglicher feinem Bruber feine Žeble.

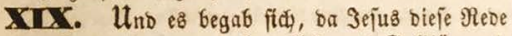

Matt. 18:35 in the Polyglotten-Bibel.

and I will pay you everything.' 27 And out of pity for him, the lord of that slave released him and forgave him the debt. ${ }^{28}$ But that same slave, as he went out, came upon one of his fellow slaves who owed him a hundred denarii; and seizing him by the throat, he said, 'Pay what you owe.' 29 Then his fellow slave fell down and pleaded with him, 'Have patience with me, and I will pay you.' $3^{\circ}$ But he refused; then he went and threw him into prison until he would pay the debt. ${ }^{31}$ When his fellow slaves saw what had happened, they were greatly distressed, and they went and reported to their lord all that had taken place. 32 Then his lord summoned him and said to him, 'You wicked slave! I forgave you all that debt because you pleaded with me. 33 Should you not have had mercy on your fellow slave, as I had mercy on you?' 34 And in anger his lord handed him over to be tortured until he would pay his entire debt. 35 So my heavenly Father will also do to every one of you, if you do not forgive your brother or sister from your heart."'

The concluding section of Matthew 18 contains a teaching on the importance of forgiveness, already summed up earlier in the Gospel narrative (Matt. 6:14-15): 'For if you forgive others their trespasses, your heavenly Father will also forgive you; but if you do not forgive others, neither will your Father forgive your trespasses.' This teaching is now deepened in the form of a parable, the message of which is highly intimidating and indirectly accusatatory. At the end of the parable, the lord hands his servant over 'to be tortured until he paid his entire debt'. This is a representative example of the rhetoric of intimidation in Matthew and anticipates the supernatural punishment awaiting 'wicked slaves' in the judgement at the end of the world.

In a broader view, the Gospel of Matthew is very rich in both the amount and quality of its language of intimidation. Verbal threats seem to be a rhetorical tool constantly used by its main character, Jesus, in connection with his major theme of teaching, namely the end of time and the last judgement. These topics are brought out both through teachings in parables, especially in chapters 24-5, and through direct appeals to the audience. The language of intimidation is sometimes simple, even subtle, reference to the coming judgement or some sort of punishment, but often consists of visually rich and emotionally loaded portrayal of punishment (Henning 2014). The audiences and the targets of the threats include the adversaries of Jesus, most notably the Pharisees, but sometimes also his followers. Usually, the threatening language in his teachings seems to address people in general: the punishment is about to suddenly come upon everyone living in sin, and the only way for anyone to avoid this is to live according to his teaching. From the perspective of spiritual violence, Matthean rhetoric of intimidation is a true treasury to be exploited for religious abuse.

The rhetoric of accusation in the 
passage quoted is directed at the slave behaving in a pitiless way in the parable story of Jesus (Matt. 18:32-3): 'You wicked slave! I forgave you all that debt because you pleaded with me. Should you not have had mercy on your fellow slave, as I had mercy on you?' This accusation is then directed at the audiences of the parable in a conditional manner (18:35): 'So my heavenly Father will also do to every one of you, if you do not forgive your brother or sister from your heart.' This teaching is a good example of the extensive and demanding rhetoric of accusation in Matthew, which is often also intimidating rhetoric of control. In this way, the Gospel of Matthew sets proverbially high moral standards for its audience (5:20): 'For I tell you, unless your right-

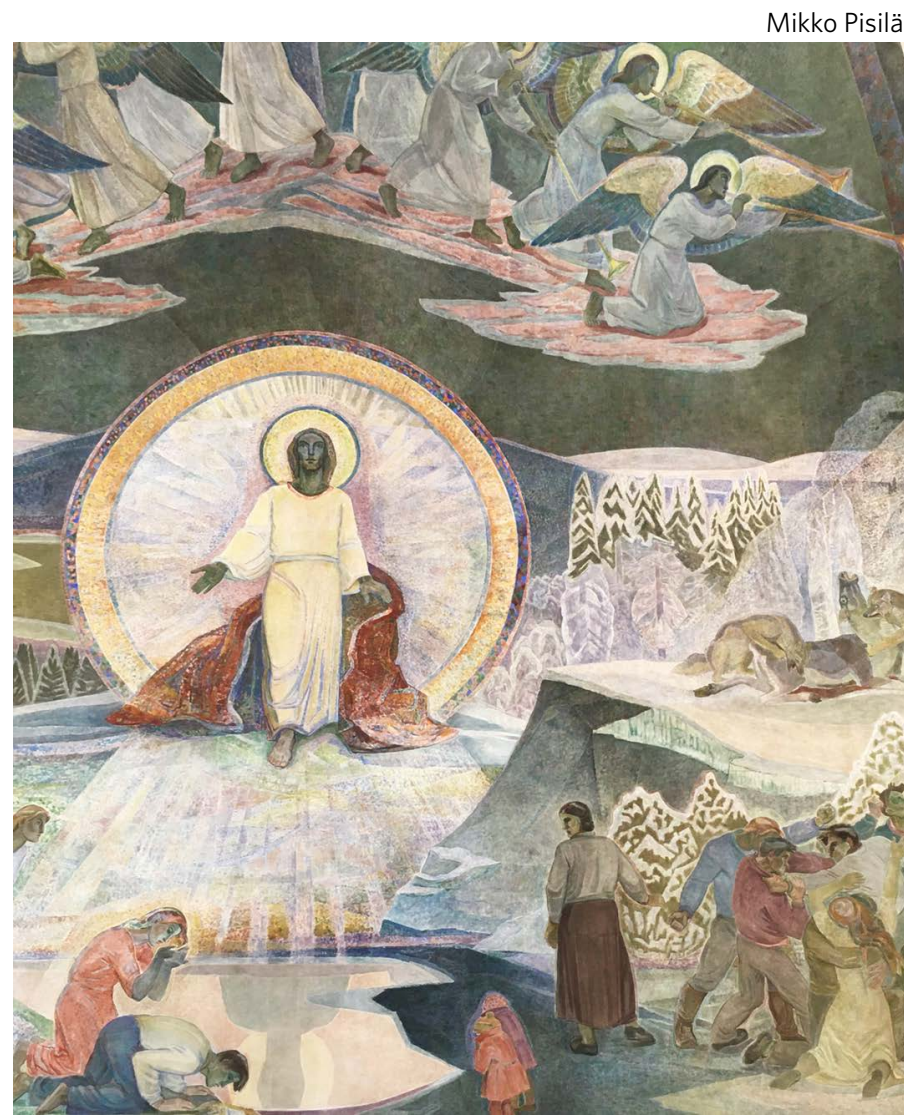

Part of the fresco Fountain of Life (1951) by Lennart Segerstråle at the altar of the Rovaniemi Evangelical Lutheran Church. eousness exceeds that of the scribes and Pharisees, you will never enter the kingdom of heaven.' This righteousness demands showing perfect love to everyone (5:44-8), and even an unclean thought is proved to be wrong and punishable (5:28).

In summary, accusation is an essential tool in the rhetoric of the Gospel of Matthew. In the Sermon on the Mount, Jesus points out his way of righteousness by showing examples of the opposite conduct. As a reaction to the teaching and action of Jesus, his adversaries often accuse him - and his disciples, as well - of incorrect behaviour and even of exploiting demonic powers. Jesus often answers these accusations with counter-accusations, a collection of which is found in chapter 23. Sometimes Jesus accuses certain cities, and often his whole generation, of ignoring the message conveyed by him and John the Baptist. The rhetoric of accusation is also present in the eschatological teachings of Jesus, in many of which a king or rich man makes accusations against his subjects. Apart from John the Baptist being executed after accusing Herod of adultery, Jesus is finally accused and executed after making accusations against the temple trade and the Pharisean way of life (Matt. 21:13, 23:2-31). From the perspective of spiritual violence, the rhetoric of accusation in the Gospel of Matthew may be useful for psycho-social abuse.

Being conscious of the limited and pessimistic perspective of the analysis above, I would like to finish with a quotation from Jack David Eller: 
Much good has come from religion. Much harm has also come from it. And much harm has also come from sources other than religion. However, we find that the characteristics of religion - its group nature, its authority principles, its identity aspects, its practical interests, and its specific ideologies - can be and have been particularly productive of violence. ... Religion is diverse, ambiguous, and cultural, and violence is equally diverse, ambiguous, and cultural. Alloyed as they can be, they produce stunning and alarming arrays of religion-inspired and often religion-sanctioned violence. Violence, therefore, is neither native to nor foreign to religion. Rather, it should be said that both violence and religion are native to humans, and they will find their way together. (Eller 2007: 246)

\section{Conclusion}

Having assessed the Gospel of Matthew as a whole, and having demonstrated my approach with an analysis of the eighteenth chapter, I have pointed out that the text shows the presence of every trait of spiritual violence under consideration here. These traits often tend to occur together in certain passages. Intimidation seems to be the central rhetorical tool of the Matthean Jesus, closely linked to accusation. Conversion is the explicit rhetorical aim of the text, as a gateway leading into a controlled way of life. Regarding isolation, ethnic categorizations seem to lose their power in Matthew's narrative. However, religious categories and borders are constantly manifested. In terms of the supernatural punishment hypothesis, the rhetoric of the Gospel of Matthew presents a system of supernatural surveillance and punishments, complemented with social ones.
Throughout history, extensive use of the rhetoric of the Gospel of Matthew has been a recognizable part of the spread of Christianity. From the perspective of supernatural punishment, this article has presented detailed information on the cultural evolutionary side of the hypothesis in the case of the most influential world religion. On the other hand, this article has connected the discourse of spiritual violence with the cognitive and evolutionary roots of the religious use of power. My suggestion is that understanding both the genetic and cultural origins of religion may help those suffering religious abuse, and those supporting them. In this article, I have aimed to show an example of such an understanding.

The cross-disciplinary methodology of this article also opens perspectives in the field of exegetics, for broadening the sociorhetorical understanding of the ancient texts. Even though the supernatural punishment hypothesis does not pretend to be the only explanation for religion and the existence of associated texts, I suggest that the evolutionary understanding provided by the hypothesis, and the associated cognitive and evolutionary research, might be of use in exegetics. This sort of exegetics might also be fruitful when combined with comparative study of religion, noting the obvious similarities between the rhetoric of hell in the Gospel of Matthew and the Quran, to begin with.

My analysis has also been a test of the exegetical use of the concept of spiritual violence. Whether or not this has been a success is to be judged by the reader, especially noting the political nature of the concepts of violence and spiritual violence. However, the main result of my analysis is clear and relevant: the rhetoric of the Gospel of Matthew has great potential for the misuse of religious power. Let us 
handle it with care, as scholars and human beings.

Mikko Pisilä Th.M. is a doctoral student at the doctoral programme in social and cultural encounters at the University of Eastern Finland. He is studying the Gospel of Matthew as an instrument of group commitment. Pisilä is interested in the sacrificial and violent dimensions of group life and the social, cognitive and evolutionary dynamics behind these dimensions.

\section{References}

Brown, Francis, S. R. Driver, Charles A. Briggs, Edward Robinson, Wilhelm Gesenius, and James Strong. 2001. The Brown-DriverBriggs Hebrew and English Lexicon. With an appendix containing the Biblical Aramaic. Coded with the numbering system from Strong's Exhaustive Concordance of the Bible (Peabody, MA: Hendricksons Publishers).

Carter, Warren, 2005. 'Constructions of violence and identities in Matthew's Gospel', in Violence in the New Testament, eds. Shelly Matthews and E. Leigh Gibson (New York: T\&T Clark).

Davies, W. D., and Dale C. Allison. 2004a. A Critical and Exegetical Commentary on the Gospel According to Saint Matthew in Three Volumes, vol. I: Introduction and Commentary on Matthew I-VII, The International Critical Commentary on the Holy Scriptures of the Old and New Testaments (London: T\&T Clark).

Davies, W. D., and Dale C. Allison. 2004b. A Critical and Exegetical Commentary on the Gospel According to Saint Matthew in Three Volumes, vol. II: Commentary on Matthew VIII-XVIII, The International Critical Commentary on the Holy Scriptures of the Old and New Testaments (London: T\&T Clark).

Eller, Jack David. 2007. Introducing Anthropology of Religion (New York: Routledge).

Galtung, Johan. 1969. 'Violence, peace, and peace research', Journal of Peace Research 6(3): 167-91, doi: <https://doi.org/10.1177 /002234336900600301>.
Galtung, Johan. 1996. 'Cultural violence', in Peace by Peaceful Means. Peace and Conflict, Development and Civilization (London: SAGE Publications), 196-210, doi: <https:// doi.org/10.4135/9781446221631.n17>.

Gaventa, Beverly Roberts. 1992. 'Conversion in the Bible', in Handbook of Religious Conversion, eds. H. Newton Malony and Samuel Southard (Birmingham: Religious Education Press).

Hagner, Donald A. 1995. Matthew 14-28, Word Biblical Commentary $33 \mathrm{~B}$ (Dallas, TX: Word).

Henning, Meghan. 2014. Educating Early Christians through the Rhetoric of Hell. 'Weeping and Gnashing of Teeth' as Paideia in Matthew and the Early Church, Wissenschaftliche Untersuchungen zum Neuen Testament 2, Reihe 382 (Tübingen: Mohr Siebeck).

Hurtig, Johanna. 2013. Taivaan taimet. Uskonnollinen yhteisöllisyys ja väkivalta (Tampere: Vastapaino).

Johnson, Dominic D. P. 2005. 'God's punishment and public goods. A test of the supernatural punishment hypothesis in 186 world cultures', Human Nature 16(4): 410-46, doi: <https://doi.org/10.1007/ s12110-005-1017-0>.

Johnson, Dominic D. P. 2016. God is Watching You. How the Fear of God Makes us Human (Oxford University Press).

Johnson, Dominic D. P. 2018. 'The wrath of the academics: criticisms, applications, and extensions of the supernatural punishment hypothesis', Religion, Brain \& Behavior 8(3): 320-50, doi: <https://doi.org/10.1080/2153 599X.2017.1302986>.

Johnson, Dominic D. P., and Oliver Krüger. 2004. 'The God of wrath. Supernatural punishment and the evolution of cooperation', Political Theology 5(2): 159-76, doi: <https:// doi.org/10.1558/poth.2004.5.2.159>.

Johnson, Luke T. 1989. 'The New Testament's anti-Jewish slander and the conventions of ancient polemic', Journal of Biblical Literature 108(3): 419-41.

Jussila, Jarmo, Mikko Oinonen, Juhana Unkuri, and Osmo Vatanen. 2004. Kirkon ja uskon sanakirja. Aamenesta öylättiin (Helsinki: Kirjapaja).

Lampe, Peter. 2010. 'Can words be violent or do they only sound that way? Second 
Corinthians: verbal warfare from afar as a complement to a placid personal presence', in Paul and Rhetoric, eds. J. Paul Sampley and Peter Lampe (London: T\&T Clark), 223-39.

Levine, Amy-Jill, and Marc Zvi Brettler (eds.). 2011. The Jewish Annotated New Testament: New Revised Standard Version (Oxford University Press).

Liddell, Henry George, Robert Scott, Henry Stuart Jones, and Roderick McKenzie. 1996. A Greek-English Lexicon. With a Revised Supplement (Oxford: Clarendon Press).

Linjakumpu, Aini. 2012. Haavoittunut yhteisö. Hoitokokoukset vanhoillislestadiolaisuudessa (Tampere: Vastapaino).

Linjakumpu, Aini. 2015. Uskonnon varjot. Hengellinen väkivalta uskonnollisissa yhteisöissä (Tampere: Vastapaino).

Linjakumpu, Aini. 2016. 'Väkivalta uskonnollisissa liikkeissä. Teoreettisia lähtökohtia hengellisen väkivallan tutkimiseen', Politiikka 58(3): 179-92.

Luz, Ulrich. 2001. Matthew 8-20: A Commentary, Hermeneia: A Critical and Historical Commentary on the Bible (Minneapolis: Fortress Press).

Luz, Ulrich. 2005. Matthew 21-28: A Commentary, Hermeneia: A Critical and Historical Commentary on the Bible (Minneapolis: Fortress Press).

Merleau-Ponty, Maurice. 2006. Phenomenology of Perception, trans. C. Smith (London: Routledge).

Nestle, Erwin, and Eberhard Nestle. 2008. Novum Testamentum Graece et Latine: Editio XXVII, eds. Barbara Aland, Kurt Aland, Johannes Karavidoupoulos, Carlo M. Martini, and Bruce M. Metzger (Stuttgart: Deutsche Bibelgesellschaft).

Olivares, Carlos. 2016. The (Im)Polite Jesus. An Analysis of Jesus' Verbal Rudeness in Matthew's Gospel, Studies in Biblical Literature 167 (New York: Peter Lang).

Purzycki, Benjamin Grant, Coren Apicella, Quentin D. Atkinson, Emma Cohen, Rita Anne McNamara, Aiyana K. Willard, Dimitris Xygalatas, Ara Norenzayan, and Joseph Henrich. 2016. 'Moralistic gods, supernatural punishment and the expansion of human sociality', Nature 530: 327-30, doi: <https://doi.org/10.1038/ nature $16980>$.
Runesson, Anders. 2008. 'Re-thinking early Jewish-Christian relations: Matthean community history as Pharisaic intragroup conflict', Journal of Biblical Literature 127(1): 95-132, doi: <https://doi.org/10.2307/25610109>.

Runesson, Anders. 2016. Divine Wrath and Salvation in Matthew: The Narrative World of the First Gospel (Minneapolis, MN: Fortress Press).

Ruoho, Aila. 2013. Päästä meidät pelosta. Hengellinen väkivalta uskonnollisissa yhteisöissä (Helsinki: Nemo).

Staudigl, Michael. 2007. 'Towards a phenomenological theory of violence. Reflections following Merleau-Ponty and Schutz', Human Studies 30(3): 233-53, doi: <https:// doi.org/10.1007/s10746-007-9057-6>

Tobin, Theresa W. 2019. 'Religious faith in the unjust meantime. The spiritual violence of the clergy sexual abuse', Feminist Philosophy Quarterly 5(2), doi: <https://doi. org/10.5206/fpq/2019.2.7290>.

Villa, Janne. 2013. Hengellinen väkivalta (Helsinki: Kirjapaja). 